\title{
EVALUATION OF THE EMERGENCE OF IMIDAZOLINONE RESISTANT WEEDY RICE (ORYZA SATIVA L.) IN MALAYSIA
}

\author{
BZOUR, M. I. ${ }^{1}-$ ZUKI, F. M. ${ }^{2}-$ MisPAN, M. S. ${ }^{*}$ \\ ${ }^{1}$ Institute of Biological Sciences, Faculty of Science, Universiti Malaya, 50603 Kuala Lumpur, \\ Malaysia \\ (phone: +603-7967-6757; fax: +603-7967-4376) \\ ${ }^{2}$ Department of Chemical Engineering, Faculty of Engineering, Universiti Malaya, 50603 \\ Kuala Lumpur, Malaysia \\ ${ }^{*}$ Corresponding author \\ e-mail: shakirin@um.edu.my \\ (Received $19^{\text {th }}$ Apr 2020; accepted $14^{\text {th }}$ Sep 2020)
}

\begin{abstract}
The Clearfield ${ }^{\circledR}$ Rice Production System (CPS) technology successfully manages weedy rice infestation and increases rice production in Malaysia. However, there were concerns on the recurring presence of weedy rice in the CPS fields in recent years, suspecting that weedy rice has become resistant to the imidazolinone (IMI) herbicide. This research was designed to evaluate the occurrence of herbicide resistant weedy rice in the CPS fields. A total of 17 weedy rice biotypes were collected and assessed for resistance to IMI (imazapic + imazapyr) during germination and vegetative stages using different herbicide concentrations. Different dosages of IMI herbicide only reduced germination rate by $\sim 30 \%$ but significantly decreased the weedy rice seedlings' viability. Low viability rate for commercial (13.9 $\pm 13.8 \%)$ and double $(7.3 \pm 4.1 \%)$ herbicide dose indicated application of IMI herbicide as pre-emergence herbicide was effective to control weedy rice. The application of IMI herbicide at later stage after the recommended period increased weedy rice escape potential in the CPS fields by $64.7 \%$ to $76.5 \%$ for one- and two-dose applications, respectively. There is a possibility that weedy rice in Malaysia has developed certain levels of resistance towards IMI herbicide. Stringent ecological risk evaluation of CPS is needed to mitigate the development of herbicide resistant weedy rice in the future.
\end{abstract}

Keywords: Clearfield ${ }^{\circledR}$ rice, direct-seeding, herbicide application, herbicide resistant, weed management

\section{Introduction}

Weedy rice (Oryza sativa L.) is one of the notorious weed species in rice granaries all over the world. In most rice agroecosystem, the spread of weedy rice becomes significant mainly after the shift from rice transplanting to direct seeding (Azmi and Karim, 2008; Chauhan, 2013). The herbicide-tolerant Clearfield ${ }^{\circledR}$ rice technology (Croughan, 2003) provides an option to control weedy rice in rice agroecosystems using imidazolinone herbicides. An herbicide-tolerant rice cultivar from Clearfield ${ }^{\circledR}$ Rice Production System (CPS) was introduced to Malaysian rice farmers in 2010 as the current best solution to combat weedy rice especially in direct-seeding system (Azmi et al., 2012). This imidazolinone tolerant variety (IMI-TR) rice was developed by crossing United States IMI-TR Line No. 1770 with local cultivar, MR220, using a conventional breeding technique (Azmi et al., 2012). Introduction of CPS as a pilot study in Seberang Perak rice granaries has become popular to other rice growing states (i.e., Selangor and Kedah) because of the success of this system to control many grasses weed species including weedy rice while boosting rice production (Sudianto et al., 2013).

This system used imidazolinone (IMI) herbicide (a.i. imazapic + imazapyr) which is a selective herbicide that inhibits the ALS enzyme and the three amino acid branched 
chains: isoleucine, leucine, and valine. It stops protein synthesis, and eventually, kills any susceptible plants (weeds) including weedy rice (Azmi et al., 2012; Sudianto et al., 2013). This system reported to increase yield production by 5 to 8 times (Azmi et al., 2012). Despite the current popularity of CPS in most major rice granaries in Malaysia, Sudianto et al. (2013) has listed four major challenges for this system to become sustainable in Malaysia including the evolution potential of the weedy rice to be resistant to the herbicide application.

Low levels of natural hybridization were known to occur between the rice cultivars and weedy rice with gene flow generally ranges from $0.003 \%$ to $0.25 \%$ (Gealy, 2005; Shivrain et al., 2008). Engku et al. (2016) also observed that Clearfield®-weedy rice hybrids can occur within $5 \mathrm{~m}$ distance. IMI resistant weedy rice populations were reported in the United States after two cropping seasons (Burgos et al., 2008, 2014) and similar events were reported in other countries adopting similar CPS technology (Gressel and Valverde, 2009; Busconi et al., 2012; Scarabel et al., 2012; Rosas et al., 2014). Unfortunately, Malaysia has high potential risks of gene flow and evolution of resistant weedy rice populations because of multiple cropping of rice in a year and freezing temperatures, which would reduce the density of volunteer plants, do not occur (Shivrain et al., 2008; Burgos et al., 2014).

Despite various reports of gene flow and IMI-tolerance weedy rice in the world, there are still limited reports or evidences on weedy rice IMI resistant status in Malaysia. A preliminary study at three townships in Kedah reported that there is high likely that weedy rice has developed resistance to IMI herbicide at various level (Hamdani et al., 2015) based on the weedy rice escapes in CPS rice fields in these areas (Jaafar et al., 2014). Dilipkumar et al. (2018) reported the resistant biotype of weedy rice in Malaysia can be 2.1 to 2.8 times more resistant than the Clearfield ${ }^{\circledR}$ rice itself. Harun et al. (2018) also reported the farmers concern on the recurring weedy rice existence in the CPS fields and the potential of weedy rice resistance to IMI herbicide.

Herbicide resistance in weed population is heritable and in fact is evolution in action (Baki, 2010). This attribute indicates that weed exposure to herbicides is less likely to cause mutation but rather, an herbicide resistance weed (HRW) arises from natural selection of genetic variants possessed among weed populations (Barret and Schluter, 2007; Neve et al., 2009). Weeds in ecosystems always retain a certain level of genetic diversity to survive in a balance ecosystem until a new stress imposing to the population (Novoplansky, 2009). This instituting extra pressures to nature to inevitably response with the landscape shifts. Weeds did not change to become resistant; instead the fittest genotype was selected to survive in a changed environment (Ammann, 2000; Gressel, 2000; Gienapp et al., 2008; Heap, 2019). This study was designed to evaluate the resistant status of weedy rice from various populations collected from CPS rice fields.

\section{Materials and Methods}

\section{Weedy rice collection}

Seeds from a total of 17 different weedy rice biotypes were sampled during harvesting period in October 2016 at rice fields in Sawah Sempadan $\left(3^{\circ} 25^{\prime} 35.0724^{\prime \prime} \mathrm{N}\right.$, $101^{\circ} 10^{\prime} 36.1704^{\prime \prime}$ E) in the state of Selangor, Malaysia. Weedy rice samples were randomly selected from high weedy rice infestation fields. These weedy rice biotypes were selected due to observation of weedy rice presence despite the Clearfield $\AA$ Rice Production System (CPS) has been practiced in the fields for the past six years. 
Communication with field owners indicated that selected fields during sample collection were planted with Clearfield ${ }^{\circledR}$ rice MR220CL 2 for two consecutive seasons. Weedy rice seeds were hand-threshed and placed into an individual paper bag. Seed samples were air-dried at room temperature for 3 days (d) before placed in a $-4^{\circ} \mathrm{C}$ refrigerator for further experiments (to test for resistance to IMI herbicide). Conventional local rice cultivars MR220 and Clearfield ${ }^{\circledR}$ rice MR220CL2 certified seeds were obtained from the Muda Agricultural Development Authority (MADA).

\section{Seed bioassay with imidazolinone (imazapic + imazapyr) herbicide treatments}

The resistant of weedy rice seeds to IMI (a.i. imazapic + imazapyr) herbicide was tested by standard germination method using a half $\left(75 \mathrm{~g}\right.$ a.i. $\left.\mathrm{ha}^{-1}\right)$, single $\left(150 \mathrm{~g}\right.$ a.i. ha ${ }^{-}$ ${ }^{1}$ ), and double (300 g a.i. ha ${ }^{-1}$ ) doses of herbicide application. A sample of $\sim 30$ seeds from each weedy rice biotype was distributed in standard petri dishes $(9-\mathrm{cm}$ petri dish diameter) with a Whitman no. 1 filter paper in an incubator set at $40^{\circ} \mathrm{C}$ overnight to break the dormancy. This will eliminate the possibility of false negative germination data.

Seeds on each petri dish with three replications were then wetted with $\sim 5 \mathrm{ml}$ concentrated of IMI herbicide using $2.2 \mathrm{~g} / \mathrm{L}$ concentration for two doses, commercially concentrated $1.1 \mathrm{~g} / \mathrm{L}$ for single-dose application and $0.56 \mathrm{~g} / \mathrm{L}$ herbicide concentration for a half-dose application. The seeds for control treatment was applied with distilled water. Samples were placed in an incubator set at $30^{\circ} \mathrm{C}$ and $100 \%$ relative humidity in the light. Germinated seeds were determined by the emergence of radical or coleoptiles. The viability of germinated seedlings was determined based on the seedling appearances as viable (green in colour) and non-viable (white/non-pigmented). The germination rate and number of the viable seedlings were counted at 1, 3, 5, 7, 10 and $14 \mathrm{~d}$ after imbibition.

\section{Weedy rice growth response to imidazolinone (imazapic+imazapyr) herbicide}

After-ripened (dormancy released) seeds from all collected weedy rice biotypes and two cultivated rice were germinated in a $30^{\circ} \mathrm{C}$ incubator for $7 \mathrm{~d}$. The seedlings were transplanted into pots ( $40 \mathrm{~cm} \times 40 \mathrm{~cm}$ x $25 \mathrm{~cm}$ dimension), with 30 plants per pot. The pots were filled with clay soil mixed with growth medium and placed in water containers (60 x $120 \times 15 \mathrm{~cm}$ dimension) in a greenhouse at Rimba Ilmu, Institute of Biological Sciences, University of Malaya ( $\left.3^{\circ} 13^{\prime} \mathrm{N}, 101^{\circ} 66^{\prime} \mathrm{E}\right)$. The experimental lay out was arranged in a Complete Randomised Design (CRD) with three replications for every weedy rice population and treatment. The seedlings were carefully thinned to 25 per pot during the 2-leaf stage.

The IMI herbicide at $1.1 \mathrm{~g} / \mathrm{L}\left(150 \mathrm{~g}\right.$ a.i ha $\left.{ }^{-1}\right)$ concentration replicating the commercial dose (one-dose) was applied to the plants at 2-leaf stage ( $3 \mathrm{~d}$ after transplanting) using hand-held spray. The plant response (injury and death) to the treatment was recorded for every three days after the herbicide application. Plants with $>50 \%$ of the total leaves retained green pigmentation were considered survive from herbicide application. The second application of herbicide was applied to the plants at 21 days after first application with an increased concentration dosage to $2.2 \mathrm{~g} / \mathrm{L}$ (double dose from commercial recommended dose or $300 \mathrm{~g}$ a.i. $\mathrm{ha}^{-1}$ ) and the plant response was recorded for the subsequent three days. No application of herbicide for control treatment. A total of nine (9) morphological traits were recorded for all weedy rice populations from the control treatment (Table 1). All materials were grown with natural temperature, humidity, and day length in the greenhouse during the experiment. The water level in the pots were kept at $5 \mathrm{~cm}$ depth throughout the experiment. 
Table 1. Traits evaluated for all weedy rice biotypes collected from the Clearfield ${ }^{\circledR}$ Rice Production (CPS) fields

\begin{tabular}{c|c|c|c|c|c|c|c|c|c}
\hline \multirow{2}{*}{ Biotype ID } & \multicolumn{10}{c}{ Traits } \\
\cline { 2 - 9 } & PH & SH & PT & PC & FL & HC & HD & AN & SW \\
\hline MWR_Pop01 & 100.5 & 64 & Compact & Red & Intermediate & straw & 92 & Awn & 14.3 \\
MWR_Pop02 & 112 & 54 & Intermediate & Red & Non-erect & straw & 92 & Awnless & 16.1 \\
MWR_Pop03 & 97 & 38 & Open & Red & Intermediate & straw & 94 & Awn & 17.41 \\
MWR_Pop04 & 122 & 48 & Intermediate & White & Non-erect & straw & 93 & Awn & 17.4 \\
MWR_Pop05 & 88.5 & 60 & Compact & White & Non-erect & straw & 92 & Awnless & 14.4 \\
MWR_Pop06 & 95.5 & 35 & Intermediate & Red & Non-erect & straw & 93 & Awnless & 18.5 \\
MWR_Pop07 & 77.5 & 67 & Intermediate & Red & Intermediate & straw & 93 & Awnless & 13.4 \\
MWR_Pop08 & 98 & 35.5 & Intermediate & White & Non-erect & straw & 90 & Awnless & 17.54 \\
MWR_Pop09 & 101.5 & 46.5 & Compact & White & Non-erect & straw & 90 & Awnless & 13.7 \\
MWR_Pop10 & 112 & 64 & Intermediate & White & Erect & straw & 88 & Awn & 15.55 \\
MWR_Pop11 & 109 & 64 & Intermediate & Red & Intermediate & Furrowed & 88 & Awnless & 14.1 \\
MWR_Pop12 & 151 & 81.5 & Intermediate & White & Non-erect & straw & 84 & Awnless & 14.9 \\
MWR_Pop13 & 144 & 93.6 & Intermediate & Red & Non-erect & straw & 89 & Awnless & 17.4 \\
MWR_Pop14 & 139.5 & 75 & Intermediate & Red & Non-erect & straw & 88 & Awnless & 14.2 \\
MWR_Pop15 & 145 & 91.5 & Open & Red & Non-erect & straw & 86 & Awnless & 18.8 \\
MWR_Pop16 & 151.5 & 77.6 & Open & Red & Non-erect & straw & 87 & Awnless & 18.33 \\
MWR_Pop17 & 147 & 91.3 & Intermediate & Red & Non-erect & straw & 82 & Awn & 19.41 \\
\hline
\end{tabular}

${ }^{\text {a }}$ Traits evaluated; $\mathrm{PH}$, plant height measured in $\mathrm{cm}$; $\mathrm{SH}$, seed shattering percentage (\%); PT, panicle type; PC, color of the pericarp; FE, flag leaf type; HC, hull color; HD, days to heading; AN, presence of awn; SW, 1000 seed weight (g)

\section{Data analysis}

The germination rate and growth response data were analysed as a one-way factorial, with different dosage of herbicide treatments as the factor. The variation was tested with ANOVA to detect difference between treatments and means were compared by Tukey's test using the SAS GLM procedure and Tukey option (SAS Institute, 2011). The level of significance was set at $\mathrm{p}<0.05$.

\section{Results}

\section{Effects of imidazolinone (imazapic + imazapyr) herbicide application during germination stage}

The average germination rate for different dosages of IMI-herbicide (imazapic+imazapyr) application after $7 \mathrm{~d}$ of herbicide treatments showed that half$(93.14 \pm 6.46 \%)$ and one- $(90.97 \pm 7.52 \%)$ dose applications were significantly higher than the double-dose $(72.57 \pm 9.43 \%)$ application (Fig. 1). Daily record of germination rate also displayed that weedy rice in the half- and one-dose treatments reached nearly full germination capacity at $4 \mathrm{~d}$ after imbibition while the double-dose treatment showed slower rate at $5 \mathrm{~d}$ after imbibition. At this pre-emergence treatment (germination test), imazapic+imazapyr only reduced $\sim 10 \%$ and $\sim 30 \%$ germination percentage under commercial- and double-dose herbicide applications, respectively indicating that this herbicide has limited effect on the germinability of weedy rice. Under controlled condition (germination with distilled water), all weedy and cultivated rice recorded near $100 \%$ germination rate (data not shown). However, this germination data cannot be an indication of resistant level in weedy rice because the fate of survival of the seedlings to 
maturity are yet to be determined. Therefore, the pigmentation of the seedlings was observed to determine the seedlings potential viability.

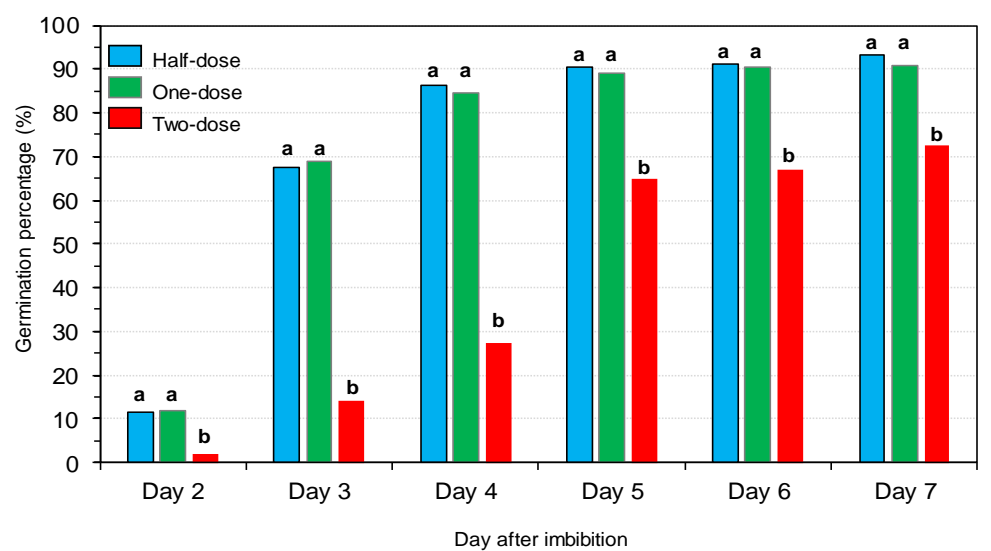

Figure 1. Cumulative germination percentage recorded for $7 d$ after imidazolinone herbicide treatment at half $(1.1 \mathrm{~g} / \mathrm{L})$, single $(2.2 \mathrm{~g} / \mathrm{L})$, and double $(4.4 \mathrm{~g} / \mathrm{L})$ herbicide concentration represented by blue, green and red column bars, respectively. Bars with the same letter show no significant difference $(p<0.05)$ within the treatments

Viability of seedlings post germination after IMI-herbicide treatments at different dosage was determined by the green pigmentation of the seedlings $14 \mathrm{~d}$ after imbibition (Fig. 2). Seedlings developed normal (green) pigmentation after treatments were counted as 'survived' from herbicide treatment and considered resistant towards the herbicide treatment while unpigmented (white color) seedlings were considered not be able to endure through maturity. The seedlings viability percentage was significantly reduced over the increment of herbicide dosage (Fig. 3). Increment from half-dose to one-dose significantly $(p<0.001)$ decreased seedlings survival by $45.8 \%$ while two-dose herbicide treatment decreased seedlings survivability by $64.8 \%(p=0.0017)$.

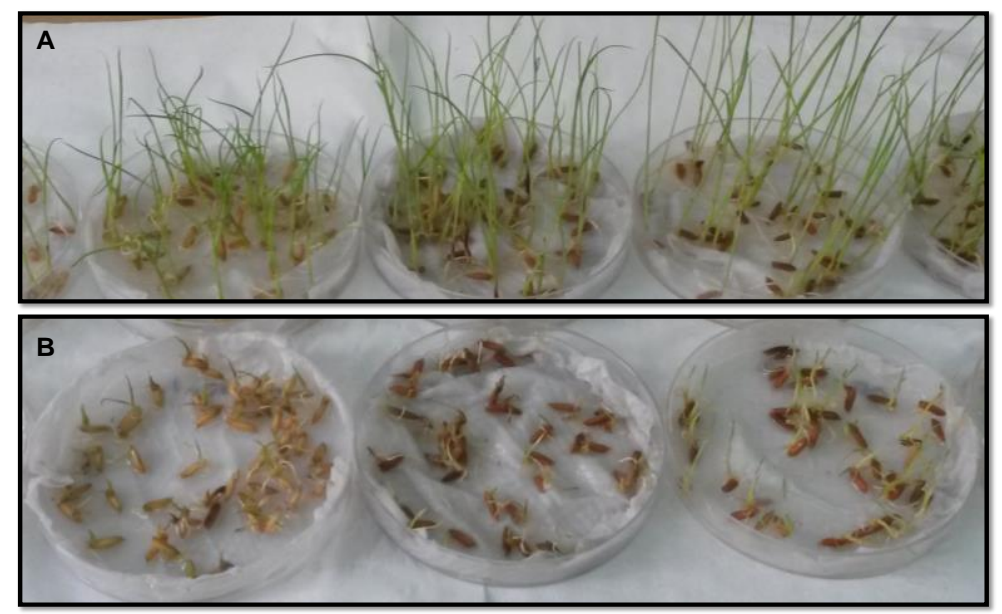

Figure 2. Weedy rice seeds' response towards pre-emergence imidazolinone herbicide treatments. The seedlings' viability was determined based on green (A) and white (B) appreances to indicate viable and non-viable seedlings, respectively 


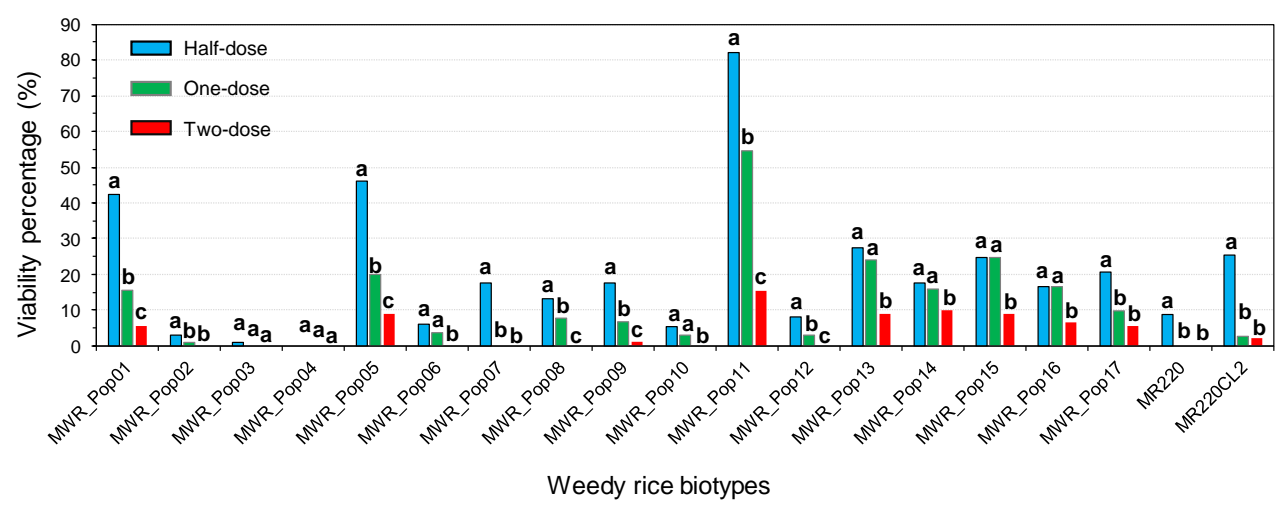

Figure 3. Percentage of seedlings viability for each weedy rice biotypes after $14 \mathrm{~d}$ of imidazolinine herbicide treatments at half $(1.1 \mathrm{~g} / \mathrm{L})$, single $(2.2 \mathrm{~g} / \mathrm{L})$, and double $(4.4 \mathrm{~g} / \mathrm{L})$ herbicide concentration represented by blue, green and red column bars, respectively. Bars with the same letter show no significant difference $(p<0.05)$ within the treatments

At half dosage of IMI-herbicide, average percentage of viable seedlings ranged from $1 \%$ to $82 \%$ while weedy rice MWR_Pop04 displayed no seedlings developing green pigmentation (Fig. 3). This indicates that this weedy rice population was the most susceptible population towards IMI herbicide. Application of IMI-herbicide at one-dose displayed three weedy rice populations were fully controlled (susceptible) at this application rate. Additional five weedy rice biotypes displayed susceptibility towards the herbicide when the dosage was increased to double the recommended dosage (Fig. 3).

Current recommended dosage of IMI herbicide with herbicide concentration of $150 \mathrm{~g}$ a.i. ha ${ }^{-1}$ only successful to control $23.5 \%$ of weedy rice biotype samples as preemergence herbicide. Despite relatively low percentage of viable seedlings $(13.9 \pm 13.8 \%)$ for the remaining 13 populations, weedy rice has developed a degree of resistance to potentially escape current herbicide dosage. At an increased dosage, IMI herbicide can control half of the weedy rice population but the remaining still maintaining low level of resistance ranging from $1.1 \%$ to $15.6 \%$. Weedy rice MWR-Pop11 displayed the most resistant population with 54.44 and $15.56 \%$ of its seedlings survived the herbicide treatments at one- and two-dose application, respectively. Clearfield ${ }^{\circledR}$ rice MR220CL2, an imidazolinone tolerant rice, displayed $25.56 \%, 2.67 \%$, and $2.22 \%$ seedlings viability percentage after herbicide application at half-, one- and two-doses, respectively.

\section{Weedy rice growth response on imidazolinone herbicide application}

The effects of IMI herbicide to weedy rice growth varied between biotypes (Fig. 4). A total of $11(64.71 \%)$ weedy rice biotyeps responded to one-dose herbicide application after $3 \mathrm{~d}$ with mortality ranging from $1.4 \%$ to $6.4 \%$. The mortality rate was gradually increased over time for the majority of the populations except for four biotypes (MWR_Pop03, MWR_Pop12, MWR_Pop13, and MWR_Pop17) which showed stagnant mortality below 10\% starting at day 15 and two populations (MWR_Pop15 and MWR_Pop16) have all plants survived commercial dose of IMI herbicide. At $21 \mathrm{~d}$ after one-dose herbicide application, weedy rice populations MWR_Pop06, MWR_Pop07, MWR_Pop08, and MWR_Pop11 showed high susceptibility to the herbicide treatment where all individuals died from the treatment. 


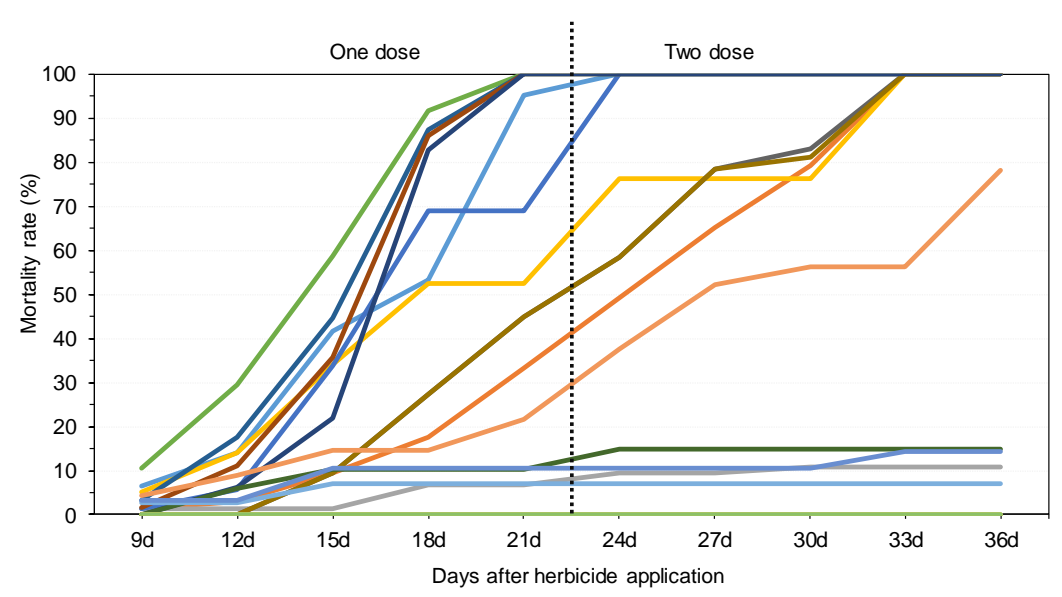

Figure 4. Effects of imidazolinone herbicide on mortality rate to 17 weedy rice biotypes over time. Vertical dotted line indicates the time of the two-dose herbicide concentration application

The increase dosage of herbicide after $21 \mathrm{~d}$ to two-dose affected the other six weedy rice biotypes where MWR_Pop01 and MWR_Pop05 reached 100\% mortality seven days after the 2-dose treatment while MWR_Pop02, MWR_Pop04, MWR_Pop09, and MWR_Pop10 died at day 37 (Fig. 4). The increased mortality rate of MWR_Pop14 however stopped at $78.3 \%$. The remaining weedy rice biotypes showed no effect (survived) or stagnant mortality rate for both application dosages.

Clearfield $\AA$ rice variety MR220CL2 showed complete resistant towards IMI herbicide of both dosages while commercial variety MR220 displayed total susceptible to the herbicide (Fig. 5). A total of two weedy rice biotypes (MWR_Pop15 and MWR_Pop16) showed similar resistant pattern with Clearfield $\AA$ rice. Figure 4 also showed that IMI herbicide can have total control to only $23.52 \%$ and $35.29 \%$ of the weedy rice biotypes for one- and two-dose applications, respectively. The remaining $41.18 \%$ of the weedy rice biotypes showed certain degrees of resistance towards herbicide application ranging from 4.74 to $100 \%$.

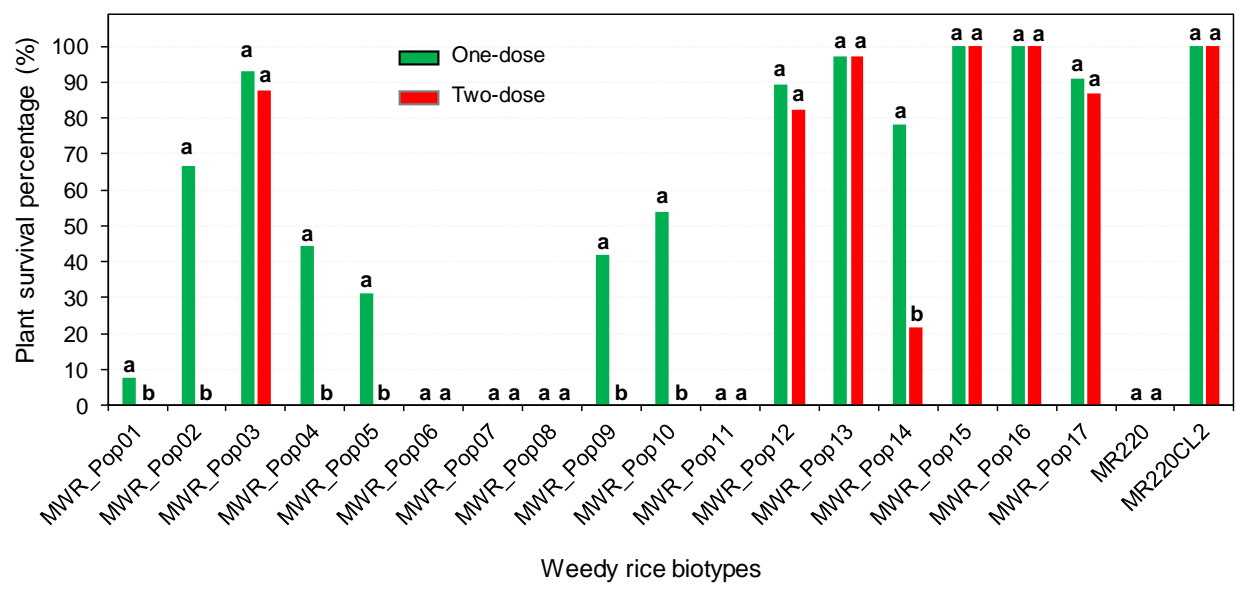

Figure 5. The growth response (survival rate) of weedy and cultivated (MR220 and MR220CL2) rice after imidazolinine herbicide treatments at commercial (150 ga.i. ha $\left.\mathrm{a}^{-1}\right)$, and double (300 $\mathrm{g}$ a.i. ha $\mathrm{a}^{-1}$ ) herbicide concentration represented by green and red column bars, respectively. Bars with the same letter show no significant difference $(p<0.05)$ within the treatments 


\section{Discussion}

It is high likely that several weedy rice biotypes in Malaysia have already 'evolved' to be resistant to imidazolinone herbicide (a.i. imazapic + imazapyr) possibly from consequential conferment of resistant genes from Clearfield ${ }^{\circledR}$ rice to weedy rice (Shivrain et al., 2008; Jaafar et al., 2014; Dilipkumar et al., 2018). Different weedy rice biotypes from this study showed wide variation of IMI herbicide responses to the weed during preemergence (Figs. 1,3) and post-emergence (Figs. 4,5) herbicide applications at various dosage. This confirmed that sampled weedy rice biotypes have various degrees of resistant towards IMI herbicide. This variation might be caused by accidental and/or voluntary hybridization between IMI tolerant cultivated rice with weedy rice in the Clearfield ${ }^{\circledR}$ rice fields.

Engku et al. (2016) reported the potential gene flow between Malaysian Clearfield ${ }^{\circledR}$ rice (MR220CL1 and MR220CL2) to various weedy rice biotypes producing resistant progenies in the $F_{1}$ population. The hybridization introduces gene flow and subsequently increases genetic diversity and heterogeneity of the hybrid weedy rice populations (Chang, 2003), initiating hybridization-differentiation cycles of next generations (Gu et al., 2004; Mispan et al., 2013). This increases genotypic selection for adaptive/survival traits (Mispan et al., 2013; Zhang et al., 2017; Qiu et al., 2017) which later expand the probability of survival potential from selection pressure due to continuous IMI herbicide application (Kuk et al., 2008; Dilipkumar et al., 2018).

Viability percentage of the seedlings for herbicide treatment as a pre-emergence application at half-dose $(21.4 \pm 19.6 \%)$, commercial dose $(13.9 \pm 13.8 \%)$ and double-dose $(7.3 \pm 4.1 \%)$ rate (Fig. 3) indicates the application of IMI herbicide as pre-emergence herbicide might help in managing weedy rice at the early stage. Imidazolinone herbicide reportedly to have a slight effect on the percentage of seed germination in chickpea but a significant shift down in the speed of germination (Hoseiny-Rad and Jagannath, 2011). This is in line with the stewardship guideline for the Clearfield ${ }^{\circledR}$ Production System (CPS) to apply the recommended herbicide only between 0 to $7 \mathrm{~d}$ after sowing (DAS). High percentage of imazapic (52.5\%) - one of active ingredients in IMI herbicide - acting as pre-emergence herbicide might contribute to this action (Dilipkumar et al., 2018).

However, this study showed that MR220CL2 (imidazolinone tolerance variety) seeds also affected by the pre-emergence application (Fig. 5) if the seeds were directly sowed before pre-germination. The usage of IMI herbicide as pre-emergence herbicide could be more effective in transplanting method especially with an increased dosage from the commercial rate. However, the environmental impact of regular usage and high dosage of this herbicide need to be properly assessed because the current CPS practice showed potential herbicide leachate and carryover in the rice field soil (Bzour et al., 2019).

The application of IMI herbicide as a post-emergence herbicide can increase the potential of weedy rice to escape the CPS. Only $23.5 \%$ of weedy rice sampled populations can be fully controlled (susceptible) by commercial dosage and additional $35.3 \%$ were controlled by 2 -dose. The low formulation rate of imazapyr $(17.5 \%$ or equivalent of $38.5 \mathrm{~g}$ a.i. $\mathrm{ha}^{-1}$ ) as a post-emergence herbicide in the herbicide will increase the probability for diverse weedy rice populations to survive. Dilipkumar et al. (2018) reported that imazapyr can control resistant biotype of weedy rice at 4,995 g a.i. ha ${ }^{-1}$. This wide margin creates ample window for weedy rice to adapt in the CPS environment and consequently become resistant to the herbicide through spontaneous mutation over time (Tan et al., 2005; Sales et al., 2008; Kuk et al., 2008). 
Unfortunately, disobedience of some farmers to follow the CPS guidelines and stewardships has been reported (Dilipkumar et al., 2018; Harun et al., 2018) and personally observed. This include practicing CPS for more than three consecutive seasons in the same field, late application of recommended herbicide at 10 to 15 DAS, and reducing the herbicide dosage to cut input cost.

Continous application of same herbicide will enhance selection pressure for resistant weedy rice. Previous experience in Malaysia already reported that continuous use of phenoxy herbicides since late 1980s has caused the weed species shift to graminaceous species including weedy rice in Malaysia rice granaries (Baki, 2006; Baki and Shakirin, 2010; Mispan et al., 2019). Late application of IMI herbicide will reduce herbicide efficacy which leads to weedy rice survival (Dilipkumar et al., 2018). This study also showed that reducing herbicide dosage will significantly increase seedlings survivability (Fig. 3), consequently facilitate weedy rice escape in the rice fields.

\section{Conclusion}

This research demonstrated diverse weedy rice biotypes in one of the rice granaries in Malaysia have developed various degrees of resistant towards IMI herbicide (a.i. imazapic + imazapyr). Intervention strategies are required to ensure the sustainability of the CPS technology in the country (Dilipkumar et al., 2018). Understanding the escape mechanism of weedy rice from herbicide application and their adaptation strategies from dynamic changes of agronomic practices in rice cultivation is needed to offer valuable insights into weedy rice management strategies in the future. Malaysia will face ecological risks of continuous weedy rice adaptation in favor to its survival if no stringent ecological risk evaluation including the screening and mitigation strategies to break the selection of herbicide resistant weedy rice in the CPS system (Sudianto et al., 2013; Mispan et al., 2019).

Acknowledgements. This research was supported in part by the Fundamental Research Grant Scheme (FRGS), Ministry of Education (Grant no. FRGS/1/2015/SG03/UM/02/3), Bantuan Kecil Penyelidikan (BKP), Universiti Malaya (Grant no. BK044-2015), and Research University Grant (Grant no. RU0062017).

\section{REFERENCES}

[1] Ammann, K. (2000): Superweeds and transgenic plants: a risk balance analysis. Abstracts: 3rd International Weed Science Congress, p.167.

[2] Azmi, M., Karim, S. M. R. (2008): Weedy rice - Biology, ecology and management. Serdang, Malaysia: Malaysian Agricultural Research and Development Institute (MARDI).

[3] Azmi, M., Azlan, S., Yim, K., George, T., Chew, S. (2012): Control of weedy rice in directseeded rice using the clearfield production system in Malaysia. - Pakistan Journal of Weed Science Research 18: 49-53.

[4] Baki, B. B. (2006): Weed Ecology and Management in Rice Ecosystems. - Universiti Malaya Press, Kuala Lumpur, 373p.

[5] Baki, B. B. (2010): Shaping the future of weed science to serve humanity in the AsiaPacific. - Pakistan Journal of Weed Science Research 16(2): 123-138.

[6] Baki, B., Shakirin, M. M. (2010): Spatio-temporal distribution pattern of new biotypes of weedy rice (Oryza sativa L.) in Selangor North-West Project, Malaysia. - Korean Journal of Weed Science 30(2): 68-83. 
[7] Barret, R. D. H., Schluter, D. (2007): Adaptation from standing genetic variation. - Trends in Ecology and Evolution 23: 38-44.

[8] Burgos, N. R., Norsworthy, J. K., Scott, R. C., Smith, K. L. (2008): Red rice status after five years of ClearfieldTM rice technology in Arkansas. - Weed Technology 22: 200-208.

[9] Burgos, N. R., Singh, V., Tseng, T. M., Black, H., Young, N. D., Huang, Z., Caicedo, A. L. (2014): The impact of herbicide-resistant rice technology on phenotypic diversity and population structure of united states weedy rice. - Plant Physiology 166(3): 1208-1220.

[10] Busconi, M., Rossi, D., Lorenzoni, C., Baldi, G., Fogher, C. (2012): Spread of herbicideresistant weedy rice (red rice, Oryza sativa L.) after 5 years of Clearfield rice cultivation in Italy. - Plant Biology 14: 751-759.

[11] Bzour, M., Zuki, F. M., Mispan, M. S., Jodeh, S. W., Monzir, S. A. (2019): Determination of the leaching potential and residues activity of imidazolinone herbicide in Clearfield rice soil using high-performance liquid chromatography. - Bulletin of Environment Contamination and Toxicology 103: 348-353.

[12] Chang, T. T. (2003): Origin, domestication, and diversification. - In: Smith, W. C., Dilday, R. H. (eds.) Rice. Origin, History, Technology, and Production. John Wiley and Sons, Inc., Hoboken, New Jersey, pp. 3-25.

[13] Chauhan, B. S. (2013): Strategies to manage weedy rice in Asia. - Crop Protection 48: 5156.

[14] Croughan, T. P. (2003): Clearfield rice: It's not a gmo. - Louisiana Agriculture 46(4): 2426.

[15] Dilipkumar, M., Burgos, N. R., Chuah, T. S., Ismail, S. (2018): Cross-resistance to imazapic and imazapyr in a weedy rice (Oryza sativa) biotype found in Malaysia. - Planta Daninha 36: e018182239.

[16] Engku, A. K., Norida, M., Juraimi, A. S., Rafii, M. Y., Abdullah, S. N. A., Alam, M. A.

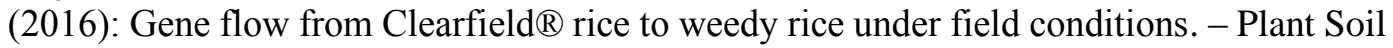
Environment 62: 16-22.

[17] Gealy, D. R. (2005): Gene movement between rice (Oryza sativa) and weedy rice (Oryza sativa): a U.S. temperate rice perspective. - In: Gressel, J. (ed.) Crop Ferality and Volunteerism. CRC Press, Boca Raton, FL, pp. 323-354.

[18] Gienapp, P., Teplitsky, C., Alho, J. S., Mills, A., Merila, J. (2008): Climate change and evolution: disentangling environmental and genetic responses. - Molecular Ecology 17: $167-178$.

[19] Gressel, J. (2000): Novel controls of millennial weeds. - Abstract: 3rd International Weed Science, p.1.

[20] Gressel, J., Valverde, B. E. (2009): A strategy to provide long-term control of weedy rice while mitigating herbicide resistance transgene flow, and its potential use for other crops with related weeds. - Pest Management Science 65(7): 723-731.

[21] Gu, X. Y., Kianian, S. F., Foley, M. E. (2004): Multiple loci and epistases control genetic variation for seed dormancy in weedy rice (Oryza sativa). - Genetics 166: 1503-1516.

[22] Hamdani, M. S. A., Juraimi, A. S., Mazlan, N. (2015): Herbicide resistant weeds in Malaysian rice fields: Will weedy rice become the next candidate? - 25th Asian-Pacific Weed Science Society Conference. Hyderabad, India, 13-16 October 2015.

[23] Harun, R., Sobri, A. A., Sufian, F. H., Sulaiman, N. H. (2018): Issues and Challenges of Clearfield $₫$ Paddy Production System among the paddy farmers in selected granary areas. - Economic and Technology Management Review 13: 63-73.

[24] Heap, I. (2019): International Survey of Herbicide Resistant Weeds. http://www.weedscience.org/In.asp. Accessed August 22, 2019.

[25] Hoseiny-Rad, M., Jagannath, S. (2011): Effect of herbicide imazethapyr (pursuit ${ }^{\mathrm{TM}}$ ) on chickpea seed germination. - Archives of phytopathology and plant protection 44(3): 224230 . 
[26] Jaafar, N. F., Juraimi, A. S., Ahmad-Hamdani, M. S., Uddin, M. K., Man, A. (2014): Distribution of weedy rice escape variants in clearfield rice production system. - Research on Crops 15(4): 754-762.

[27] Kuk, Y. I., Burgos, N. R., Shivrain, V. K. (2008): Natural tolerance to imazethapyr in red rice (Oryza sativa). - Weed Science 56: 1-11.

[28] Mispan, M. S., Zhang, L., Feng, J., Gu, X. Y. (2013): Quantitative trait locus and haplotype analyses of wild and crop-mimic traits in us weedy rice. - G3: Genes, Genomes, Genetics 3(6): 1049-1059.

[29] Mispan, M. S., Bzoor, M., Mahmod, I., MD-Akhir, A. H., Zulrushdi, A. (2019): Managing weedy rice (Oryza sativa L.) in Malaysia: challenges and ways forward. - Journal of Research in Weed Science 2: 149-167.

[30] Neve, P., Vila-Aiub, M., Roux, F. (2009): Evolutionary-thinking in agricultural weed management. - New Phytologist 184: 783-793.

[31] Novoplansky, A. (2009): Picking battles wisely: plant behavior under competition. - Plant, Cell and Environment 32: 726-741.

[32] Qiu, J., Zhou, Y., Mao, L., Ye, C., Wang, W., Zhang, J., Yu, Y., Fu, F., Wang, Y., Qian, F., Qi, T., Wu, S., Sultana, M. H., Cao, Y.-N., Wang, Y., Timko, M. P., Ge, S., Fan, L., Lu, Y. (2017): Genomic variation associated with local adaptation of weedy rice during dedomestication. - Natural Communication 8: 15323.

[33] Rosas, J. E., Bonnecarrere, V., De Vida, F. P. (2014): One-step, codominent detection of imidazolinone resistance mutations in weedy rice (Oryza sativa L). - Electronic Journal of Biotechnology 17(2): 95-101.

[34] Sales, M. A., Shivrain, V. K., Burgos, N. R., Kuk, Y. I. (2008): Amino acid substitutions in the acetolactate synthase gene of red rice (Oryza sativa) confer resistance to imazethapyr. - Weed Science 56: 485-489.

[35] Scarabel, L., Cenghialta, C., Manuello, D., Sattin, M. (2012): Monitoring and management of imidazolinone-resistant red rice (Oryza sativa L., var. Sylvatica) in Clearfield ${ }^{\circledR}$ Italian paddy rice. - Agronomy 2(4): 371-383.

[36] Shivrain, V. K., Burgos, N. R., Gealy, D. R., Moldenhauer, K. A. K., Baquireza, C. J. (2008): Maximum outcrossing rate and genetic compatibility between red rice (Oryza sativa) biotypes and ClearfieldTM rice. - Weed Science 56: 807-813.

[37] Sudianto, E., Song, B-K., Neik, T-X., Saldain, N. E., Scott, R. C., Burgos, N. R. (2013): Clearfield $\AA$ rice: Its development, success, and key challenges on a global perspective. Crop Protection 49: 40-51.

[38] Tan, S., Evans, R. R., Dahmer, M. L., Singh, B. K., Shaner, D. L. (2005): Imidazolinonetolerant crops: history, current status and future. - Pest Manage Science 61: 246-57.

[39] Zhang, L., Lou, J., Foley, M. E., Gu, X. Y. (2017): Comparative mapping of seed dormancy loci between tropical and temperate ecotypes of weedy rice (Oryza sativa L.). - G3: Genes, Genomes, Genetics 7(8): 2605-2614. 